\title{
Not Reported
}

National Cancer Institute

\section{Source}

National Cancer Institute. Not Reported. NCI Thesaurus. Code C43234.

Not provided or available. 